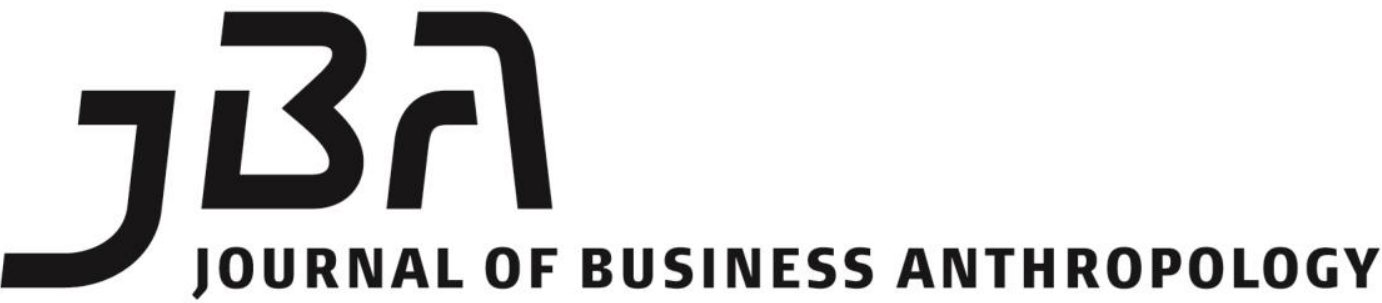

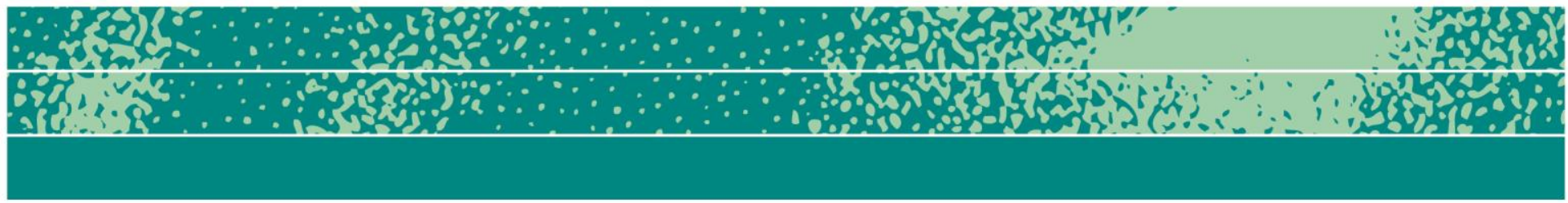

\section{Corporate Sustainability through Stakeholders' Engagement in Mining: Experiences from Shared Practices of Corporate Social Responsibility*}

\author{
Percy Arrosquipa
}

\begin{abstract}
The shared practices of corporate social responsibility with local stakeholders is one of the few relevant experiences that are undertaken to contribute to sustainable development in a mining context of high social complexity. This study characterises the relationships with local stakeholders that allow them to carry out shared practices of Corporate Social Responsibility in the district of Pataz, La Libertad Region, in the north of Peru, through two case studies and data collection that included 23 local stakeholders working with the Mining Company. This applied research included interviews and participatory observation. The findings indicated that $80 \%$ of local entrepreneurs have shown their interest in carrying out shared practices of corporate social responsibility in education, environment, health, water and sanitation, respectively. The study describes the contribution of artisanal mining enterprises and local supplier enterprises in shared practices of social responsibility, within the locations where they carry out their business activities. This research enriches knowledge of experiences that promote a shared culture of corporate social responsibility and how attending to the social demands
\end{abstract}

Page 1 of 21

JBA 10(2): 324-344 Fall 2021

(C) The Author(s) 2021 ISSN 2245-4217

www.cbs.dk/jba

10.22439/jba.v10i2.6 416 
from the perspective of the local community and business risks from the perspective of the mining company. These two sometimes conflicting perspectives coexist and complement one another for corporate sustainability after overcoming certain local and corporate paradigms which facilitates contributing to the sustainable development of the surrounding communities.

\section{Key words}

Artisanal Mining, Corporate Sustainability, Extractive Industry, Stakeholder Engagement, Social Responsibility, Shared Value.

\section{Introduction}

From its beginnings, the notion as well as the implementation of corporate practices related to social responsibility ${ }^{1}$ varies from one country to another and from one company to another (Lopez \& Contreras, 2010), thus considering the premise of creating shared value with the collaboration and participation of all actors (Murray, Haynes \& Hudson, 2010), we can find references to social responsibility in the principles of Andean reciprocity practiced by the ancient Peruvians (Franco, 2007), whose purpose was to promote the associative and collaborative spirit in Andean society.

This premise of associative collaboration to create shared value has led to the growing interest around social responsibility (Bigné, et al, 2005), whose importance in Latin America begins in the 80s of the last century, preceded two decades earlier in the United States and Europe (Reficco \& Ogliastri, 2009). Thus, social and environmental issues had entered the corporate agenda (board meeting). Also, in recent years there has been greater ecological and social awareness of citizens and/or consumers (Nieto \& Fernández, 2004). In this context, the social and environmental dimensions of business activities was deepened, which has

\footnotetext{
${ }^{1}$ There are several definitions that respond to various theoretical approaches and institutions that promote it. The UN global compact, Inter-American Development Bank, OECD guidelines, European Union green paper, The Global reporting initiative GRI, Oxfam, Institute Ethos, Mexican center for philanthropy, Peru 2021, and others. Authors such as Carroll, Wood, Michael Porter, Milton Friedman, Andrews, Richard E. Freeman, among other predecessors (Dejo, 2005) (De Pelekais \& Aguirre, 2008) (Fernández, 2005) (Correa, 2007) (López \& Contreras, 2010). (BID-Confecamaras, 2008:7) (Reficco \& Ogliastri, 2009). Most of definitions refer to the voluntary integration of social and environmental issues in business management, aligned to the guidelines of sustainable development based on an ethical, strategic and transparent relationship with its stakeholders. Thus,social responsibility is conceived, as practice of strategy management, holistic and transparent, that integrate economic, social and environmental issues, to create shared value with its stakeholders, within their surrounding where they performance and liaison.
} 
been undertaken from different theoretical approaches in social responsibility studies ${ }^{2}$. However, from the practical or applied view there are two theoretical perspectives to consider; the perspective of the shareholder engagement and the stakeholder engagement.

From the shareholder engagement perspective, a more traditional and economic approach, corporate social responsibility consists in adopting a management that emphasis maximizing economic benefits and nothing more (Calveras \& Ganuza, 2004). The main role of enterprise business is to generate profits, leaving aside the externalities caused by economic activities, in the style of the old school of Friedman (1970) that said, there is only one social responsibility of business, "to use its resources and engage in activities designed to increase its profits [...]". From this perspective, social and environmental goals are incompatible with economic goals, but today businesses cannot have sustainability in time and space if there are communities collapsing that surround them, and there is not successful businesses in a society that fails. Therefore, there is an interdependence between society and business.

From the stakeholder engagement perspective, which is a more holistic and sustainable approach, it recognized expanding the limited vision of focusing only on the economic to take consideration of the social, environmental, values [symbolic], ethics and rights issues (Argandoña,

\footnotetext{
${ }^{2}$ The theoretical perspectives are based on approaches of the [neoclassical] economy, going across sociological, administrative, anthropological and ethical (Fernández, 2005) (López \& Contreras, 2010), which contribute to a multidisciplinary approach about corporate social responsibility. Among the main theoretical approaches are: the [neoclassical] economic perspective (it back to Adam Smith, Milton Friedman, etc.) argues that the responsibility unique of company was to generate profitability for the owner or shareholders. The institutional perspective (represented by Champbell, Mayer, Pierre Bourdieu, etc.) argues that responsible corporate behavior depends on coercive, normative and mimetic factor, where the [imitations of] social responsibility practices is the result of the search for legitimacy with its social group of reference, a notion that goes beyond the shareholders when considering it as a social construction. The stakeholder perspective (among its predecessors are Richard Freeman, Porter and Kramer, etc.) associated with the strategic management theory, from the holistic vision integrate and shows relationships with different stakeholders whom interact to create shared value. The term of stakeholders was born at the Stanford Research Institute in 1963, to refer "groups without whose support the organization would cease to exist", which later Freeman would define as "any group or individual who can affect or is affected by the achievement of the organization's objectives" (Mitchell, Agle \& Wood, 1997: 854). For details of the theoretical perspectives see (Mitchell et all., 1997) (Porter \& Kramer, 2006) (López \& Contreras, 2010) (Fernández, 2005) (Ioannou \& Serafeim, 2019) (Baba, 2012). However, from a practical application of corporate social responsibility there are two theoretical perspectives. Shareholder perspective and stakeholder perspective, the first ague that economic, social and environmental objectives are incompatible, a financial approach that emphasizes the shareholder, and the second, on the contrary, maintains that the economic, social and environmental objectives are compatible and important to create shared value for all its stakeholders (Calveras \& Ganuza, 2004) (Nieto \& Fernández, 2004).
} 
2011), which is the recognition and integration of social and environmental concerns (Bigne et al., 2005). From this perspective, social responsibility consists in adopting a strategy, transparent and holistic management that emphasizes not only economic, but also social and environmental externalities. The relevant role of the business is to create shared value ${ }^{3}$ for all its stakeholders, therefore, the social, economic and environmental goals do not have to be incompatible; on the contrary, they are important in the creation of shared value (Nieto \& Fernández, 2004), there is an interdependent relationship where economic, social, environmental, values, ethics, are increasingly aligned (Reficco \& Ogliastri, 2009), thus Porter expressed "healthy businesses are intrinsically linked to healthy community" (quoted by Christensen, 2016), there is a mutual interdependence between society and business to create share value (Porter \& Kramer, 2006).

In this case, the stakeholder engagement perspective is adopted to the study of the characteristics of relationship (liaisons) inside extractive industry with its stakeholders to carry out shared practices of corporate social responsibility, which implies going beyond customer satisfaction and economic benefits, to address social and environmental needs, not only from philanthropic criteria, welfare or corporate volunteering (Prahalad \& Hammond, 2005), but from a business conception with profitability, transparency and sustainable ways, creating shared value for all its stakeholders (Bigne et al., 2005), which basically consist in aligning business success with the community success. Recent studies about the extractive industry have focused their attention on the relationship between society, environment and mining (Damonte \& Castillo, 2010), particularly anthropological studies help to have a local view of global process ${ }^{4}$ such as social inequality, participation, the relationship in [the scenario of] the extractive industry, this is considering

\footnotetext{
${ }^{3}$ Creating shared value is defined as an economic strategy that seeks the points of intersection between business and society to address issues and drive outcomes that benefit business and society simultaneously (Porter \& Kramer, 2011). Finding these points of intersection not only are an important source of economic opportunity, rather than a social obligation or cost of doing business, is a competitive advantage for differentiation, and creating shared value with community. Shared value consists, fundamentally, in aligning the successful businesses with the successful community (Porter in Christensen, 2016).

${ }^{4}$ Anthropological studies on the extractive industry began in Africa between 30s and 40 s of the last century, to understand the detribalization and urbanization processes experienced by independent African societies, social inequality, cultural diversity in extractive sceneries which difficult the forms of participation and sustainability of development, using the mining cities of Zambia as a laboratory (Damonte \& Castillo, 2010). For detail on the early relationship of anthropology with businesses see "anthropology and business: influence and interests" by Marietta Baba (2012). Similarly studies of economic anthropology have included a corporate ethnography on the consumer market, globalization, the exchange of products and services, labor changes, organizational culture, among other topics see Arrosquipa (2014), Cefkin (2012).
} 
the importance of the context where processes happen (Tilt, 2016).

At first, the relationship between companies and communities had an ethnocentric approach, which responded to the structured [Western] vision of companies but did not reflect the context of the local culture in which companies undertake their operations or activities. This has limited the ability of mining companies to build a meaningful relationship to reduce the differences between stakeholders and companies, as evidenced by the ethnographic studies conducted by Welker (2009) in Indonesia on Newmont's community relations, as well as Rajak (2011) on Angloamerican's commitment to social responsibility in its various operations at the global level (quoted by Kemp \& Owen, 2013).

That said, it is not enough to pay attention to the social, environmental and economic performance of companies from the corporate perspective. It is also very important to consider the perspective of the local community, ie both perspectives, to facilitate understanding and commitment with the stakeholders. We are not only exposed to internal ethnographic scrutiny, but also to the external scrutiny of the Stakeholders (Kemp \& Owen, 2013), which means that the socio-environmental discourse in mining at the operational level is managed not only in terms of performance, but also the social, economic and environmental impacts of an extractive activity, being prioritized simultaneously (Formentini \& Taticchi, 2016), to speak of corporate sustainability ${ }^{5}$, therefore a good relationship management and engagement to stakeholders from the beginning (Fraser, Kunz \& Batdorj, 2019), can significantly impact the viability of the company or project over time and space.

Sustainability business has recently extended the interest or concern of companies for social and environmental issues (Nieto \& Fernández, 2004) (Bigne et al., 2005) with regard to the locations where they carry out their activities, focusing their attention on health, nutrition, education, capacity building, productive infrastructure, among other topics of interest, as described in the social balance reports with little contextual reference (Tilt, 2016) or more recently, in reports on sustainability, to announce corporate performance through the management of economic, social and environmental aspects. This increasingly concern for social and environmental issues has led companies to develop corporate social responsibility practices, allocating financing for their implementation in line with their corporate policies (Arenas, Sánchez \& Murphy, 2009), since corporate social responsibility

\footnotetext{
${ }^{5}$ Corporate sustainability or business sustainability is defined in reference to the triple-bottom- line where the economic, social and environmental dimensions of business are simultaneously taken into account, therefore, corporate sustainability is understood as "the ability to conduct business with a long-term goal of maintaining the well-being of the economy, environment and society" (Hassini et al., 2012, quoted by Formentini and Taticchi, 2016)
} 
is a practice voluntary, not prescribed by law, but in the values, beliefs and symbolism of the organization. That is, its practice depends on how embedded it is in the organizational culture (Arrosquipa, 2009), and how far it determines its commitment to sustainable practices and through this, the sustainable development ${ }^{6}$ of the communities with whom they interact in the development business activities.

Those who most implement corporate social responsibility practices have been the mining and energy sector, their impacts and results have increased significantly in the last decade. In many cases these have been implemented in partnership with non-governmental development organizations (NGOs), international cooperation and the public sector (Arenas, Sánchez \& Murphy, 2009). In the case of Peru, we can see an increase in the number of companies with the emblem of a "socially responsible company" (ESR in Spanish). According to Peru2021, since the implementation of the badge in 2011 [where] only 12 companies had the ESR emblem, so far this year (2018), 110 companies have been recognized with the ESR badge (Peru2021, 2018), for their social responsibility practices, extended their practice in Perú is important to advance in sustainable development (Dejo, 2005), as well as the social investment of the extractive industry, which in Peru has reached around five billion soles over the last 10 years. (Grupo propuesta ciudadana, 2019)

These practices of corporate social responsibility have been implemented with direct financing from companies or shared with other institutions outside of the locations, to contribute to the welfare of local stakeholders (Franco, 2007), (Arbayza, Cateriano \& Mesa, 2014) (Grupo propuesta ciudadana, 2016) (Peru2021, 2017), (Arenas, Sánchez \& Murphy, 2009) (Pinto, 2015). However, sharing financing with participation of local stakeholders is not a usual circumstance, and even less so when it involves the small-scale (artisanal) mining sector, which is often stigmatized negatively in Peruvian society as a conflictive local actor $^{7}$ and contaminator (Hütz-Adams \& Müller, 2012), which in recent

\footnotetext{
${ }^{6}$ Here is adopted the definition described in 1980 by Norwegian Prime Minister Gro Harlem Brundtland, used by the World Business Council for Sustainable Development and accepted since 1987 by the World Commission on Environmental and Development in his report "our common future" such as "meet(ing) the needs of the present without compromising the ability of future generations to meet their own needs" for detail see (Murray, Haynes \& Hudson, 2010) (Porter \& Kramer, 2006) (Gómez in Raufflet et al., 2012) (Schwalb, 2008).

${ }^{7}$ Mining conflict in the 70s and 80s of the last century were essentially labor and syndical, now conflicts happen between company, surrounding communities and mining activities, for control and use of natural resources (De Echave \& Torres, quoted by Gouley, 2015). Mining conflicts are due to structural incompatibilities and deep cultural discrepancies points out Gouley (2005), which leads to the cultural disagreement between the company (Western culture) and communities (Andean culture). According to the ombudsman's office, socio environmental conflict increasing to 126 cases in 2018 at Peru level, of which two thirds (83
} 
years, with the participation and commitment of all the actors involved in mining, is a trend which it is hoped will be reversed.

Artisanal mining is an important economic activity that produces a quarter of the world's gold production (Ibid, 2012). In this context, local stakeholders (are local supplier enterprises and local mining enterprises) working with the Mining Company in Pataz town in the north of Peru, when developing its activities mainly in the gold mining sector mainly obtains benefits but also impacts the surroundings where they work. The responsibility to generate shared value in its areas of influence is therefore born, and represents a high-potential opportunity to undertake initiatives of shared practices of corporate social responsibility.

According to recent studies previously quoted on extractive industrial, the practice of corporate social responsibility have been carried out with direct financing from mining company, or shared with other institutions outside of the locations. But sharing practices of corporate social responsibility with [shared] participation of local stakeholders is not a highly studied or practiced circumstance, and even less so when it involves the small-scale (artisanal) mining sector. Therefore, it is important to know the characteristics of the [good] relationships with local stakeholders that allow the carrying out of shared practices of Corporate Social Responsibility in the district of Pataz, La Libertad Region, in the north of Peru. It is important to attend to the social demands from the perspective of the local community and business risks from the perspective of the mining company, and imperative for corporate sustainability over the long term, issues that are described below.

\section{Methodology}

Longitudinal and applied research was based on case studies and data collection that included 23 local stakeholders or local entrepreneurs, (are local supplier enterprises and artisanal mining enterprises formalized or in the process of formalization), that working with the Mining Company in the district of Pataz, in the north of Peru. This applied research involved the application of interviews through case study, application of survey to local stakeholders, and participatory observation during the course of research. To collect data by survey a questionnaire was used, it was originally designed in Spanish, because this language is spoken by the local stakeholders. To collect evidences by interviews through case study,

cases) are linked to mining, reflecting the weak governance [of natural resources], this reality that distances us from the OECD standards (see Mendoza, 2019). The recognition and respect of the rights of local communities has an important relationship with preservation of natural resources and governance, by the way conflict resolution not only passage to make visible the socioeconomic advantages, but to make visible and understanding the cultural aspect. 
semi-structured guided question was used, and fieldwork note was used as part of participatory observation, during conducted fieldwork in Pataz district with local stakeholders.

Pataz district has a population of 8,937 inhabitants (INEI, 2017), located in the province of Pataz, La Libertad region, in the north of Peru, were considered to the study. The main economic activity in the district of Pataz is gold mining [artisanal] and to a lesser extent, agriculture and livestock. This traditional form of small-scale mining has increased in Pataz. One of issues was the increase in illegal mining. "Illegal miners" were from outside area. In-migration was changing local social conditions, such as pollution, land access, dispute water resource, social inequalities (some people accessed mining benefits while other did not), increased local business, in many cases they working as local supplier enterprises and artisanal mining enterprises. The mining company supported the formalization process of many artisanal miners in Pataz ${ }^{8}$. This historical interaction that mine has had with local people, shaped the nature of relationship between company mining and local stakeholders.

Mining Company has been working on gold extractive since 1980 in the district of Pataz, currently has two production units; Santa María, located in the town of Pueblo Nuevo and Marañon, located in the town of Vijus. The project is an underground gold operation managed by national private company. It is not the only mine in the region La Libertad. The company has made a commitment to sustainable development surrounding communities and towns. In this operational context, the research process was developed to know the characteristics of relationship with local stakeholders that allow to carry out shared practices of corporate social responsibility. Fieldwork has two stages; the first stage involves the application of surveys to local stakeholders and the second stage involves conducting case studies.

In the first stage, a brief survey was prepared for data collection purposes, previously validated with six local stakeholders, to provide insights into the perceptions of local stakeholders regarding corporate social responsibility practices. The survey validated, was applied to the sample identified according to the following criterion: local stakeholders or enterprises with incomes higher than half a million dollars per year, considering the annual turnover of 2015. Theses local stakeholders involved 32 respondents, who were delivered and collected data through questionnaires validated. The fieldwork was carried out between May and July 2015 with respondents or local enterprises that meet the

\footnotetext{
${ }^{8} 270$ artisanal mining enterprises work in the district of Pataz, who was formalized with the support of mining company, while in the region of La Libertad there are 5,700 artisanal mining enterprises formalized or in the process of formalization (likewise 70 local supplier enterprises work with mining company). These local stakeholders have potential to continue with shared practices of corporate social responsibility.
} 
segmentation criteria, whose systematized information has facilitated the development of strategies to promote shared practices of social responsibility.

In the second stage, a qualitative approach has been taken in the research in order to collected the evidences from the perspective of the local stakeholders, case studies were carried out to know and explain the experiences of shared practices of social responsibility with local stakeholders through characteristics of stakeholder relationships, which during the years 2015 and 2016 co-financed community projects. In order to identify the case studies, the following criterion have been considered: local stakeholders or entrepreneurs who have had experience of having been part of the shared social responsibility practices with the Mining Company on more than two occasions, co-financing through their donation community projects in the framework of the promotion of sustainable development. The fieldwork was carried out in August and November of 2016, during this time interviews and participatory observation process was conducted with two cases: a local supplier entrepreneur and an artisanal mining entrepreneur, who were interviewed through semi-structured guided question, with an emphasis on the observation and interpretation of the engagement between the Mining company and the local population, whose information has allowed the development of an mechanism for the mobilization of donations to carry out shared practices of social responsibility.

Following the data and evidences collection process, in order to ensure the consistency of the results, the data were triangulated through the use case study interviews, survey data, evidences of participatory observation and information from secondary sources (reports, books, articles, and other company documents). A technique to do this was a descriptive analysis to the data and evidences that provided a broad view of the thematic according the main purpose of research.

\section{Findings and Discussion}

\section{Perceptions Regarding Corporate Social Responsibility Practices}

In the world of mining activity, economic, social and environmental performance is subject to the criticism and scrutiny of stakeholders, where different ideas and opinions converge on the dynamics of the mineral extraction industry as well as environmental pollution and social risks. Paying attention to both the corporate perspective and the local perspective is important for enable corporate sustainability and maintaining trust with stakeholders.

In this context, the positive perception regarding the performance of the Mining Company had surpassed more than half, reaching $60 \%$ of the local population (Poderosa 2015), which means improvement the 
process of relationship and interaction with local stakeholders, participation with social investment in their surrounding and multistakeholder collaboration. These practices improve the condition of the environmental in which companies operate, reducing social risk and increasing their reputation (Nieto \& Fernández, 2004). But not all of the local entrepreneurs or local stakeholders working in the gold mining sector as suppliers to the Mining Company, adopted the idea of contributing to the development of their communities, believing that "social responsibility is not the task of local entrepreneurs", saying "only Mining Company should carry out social responsibility", "to say that they do not impact and consider themselves outside the environment where interact", paradigms that lead them to circumvent the natural and social environment where they interact. Similar situation has been described in the United Kingdom, where small entrepreneurs thought that corporate social responsibility not apply to them, but for large companies (Jenkins, 2006).

Corporate social responsibility practices have traditionally been associated with large companies, but their significant growing in the small and medium size enterprise sector is recognized (Ibid, 2009). It is the case of local entrepreneurs who showed an interest in contributing to the development of their areas of influence; they positioned themselves as protagonists to shared practices of corporate social responsibility with the communities within their surroundings.

"We do not imagine [how to] provide social support, neither we knew how to do it. But we learned along the way with Company support, that we can collaborat[e] with education, health and sports in our community. Today the social responsibility is a practice that we [are] doing with our community" (Stakeholders: artisanal mining entrepreneur, 11/2016).

"Social responsibility for us is a commitment. It is a culture that we are already applying, in the day to day in our relations with the community..., it is not the first time, we have had experiences, that have allowed us to strengthen the relationship with the community" (Stakeholders: local supplier entrepreneur, 11/2016)

These cases show that the perception about practices of corporate social responsibility has been changing in local stakeholders, particularly those that have achieved a certain level of solvency over time, until to become entrepreneurs. Achieving what is known as business success, should go hand in hand with social progress and environmental preservation, to generate shared value with the local communities where them interact, but this situation involves previously having the willingness of the local stakeholders to contribute to their social and environmental surrounding. The findings showed that $80 \%$ of local 
stakeholders or entrepreneurs have shown their interest to carry out shared practices of social responsibility with Mining Company, cofinancing community projects in their surrounding communities.

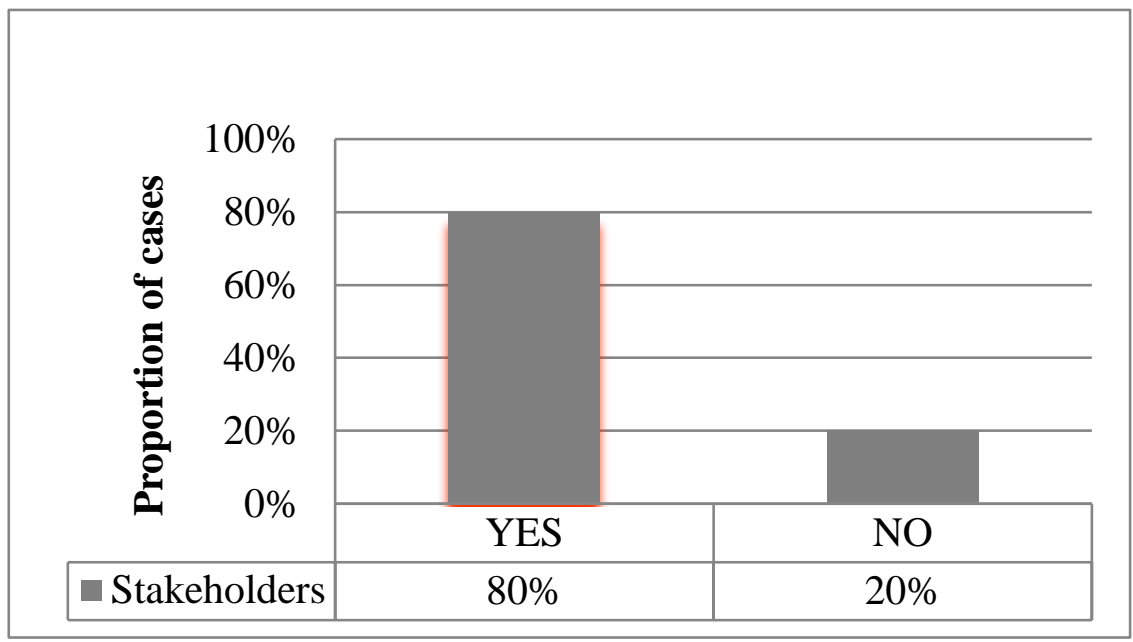

Figure 1. Perception to join in corporate social responsibility projects with Company $(\mathrm{n}=23)$

A case study research conducted in Mongolia on the creation of shared value into the extractive industry, suggests the importance of identifying points of common interests or issues shared between company and its stakeholders (Fraser, Kunz \& Batdorj, 2019). For example, investments or contributions in project like education, health, water, economic development, environment preservation, among other issues, that are viewed as priorities by communities are points of collaboration and opportunities to create shared value, and helping meaningful relationships with local stakeholders. A case of them is the willingness of local stakeholders or local entrepreneurs in the Pataz district in the north Peru, is for making contributions on issues prioritized by them as a part of the concerted local planning process in the communities and towns.

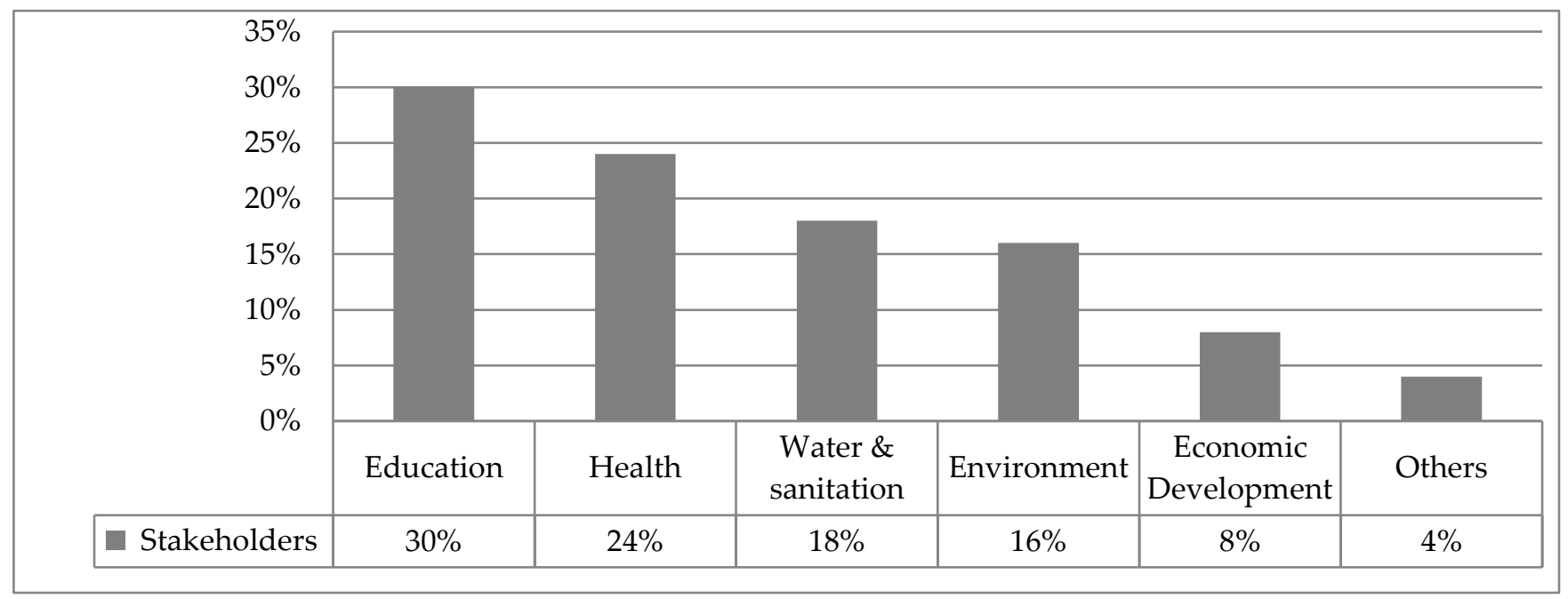

Figure 2. Willingness for making contributions with Company in areas 
prioritized by local stakeholders $(n=23)$

As can be seen, there is a strong interest on the part of local stakeholders to contribute to education, health and sanitation, a predisposition that is in accordance with the needs and demands of the communities of the district of Pataz, and the sustainable development goals promoted by UN. Therefore, these common needs or issues shared are opportunities to create share value, and continue improving local development indices of Pataz district, where the HDI is 0.4686, placing it in position 594 at the national level (UNDP, 2019). The willingness of local stakeholders or entrepreneurs to carry out shared practices of social responsibility together with the Mining Company is the starting point that enables the promotion a shared culture of social responsibility, to continue creating shared value and improve the conditions of their surrounding into operating. So, building a good relationship, find common issues of collaboration, carry out shared practices of corporate social responsibility, are aspects with [strategy] potential from the mining company to get involved and contribute to the sustainable development of the communities where they operate.

\section{Shared Practices of Corporate Social Responsibility with Local Stakeholders}

To put into practice the predisposition of local stakeholders, where many still refuse to believe that they can also generate shared value, has required overcoming certain local and corporate paradigms, to adopt a commitment to sustainable development, furthermore developing and socializing an instrument of management called protocol for the obilization of donated funds, in order to enable the contributions of local stakeholders to the communities to be made through Asociación Pataz, an entity that receives donations and was created by company to promote sustainable development. The management tool allows [co]finance local initiatives of sustainable development, to make donations by local stakeholders more feasible through their active incorporation into shared practices of social responsibility, and at the same time, accessing tax benefits for donors, such as a tax that is deductible when making institutionalized donations. 


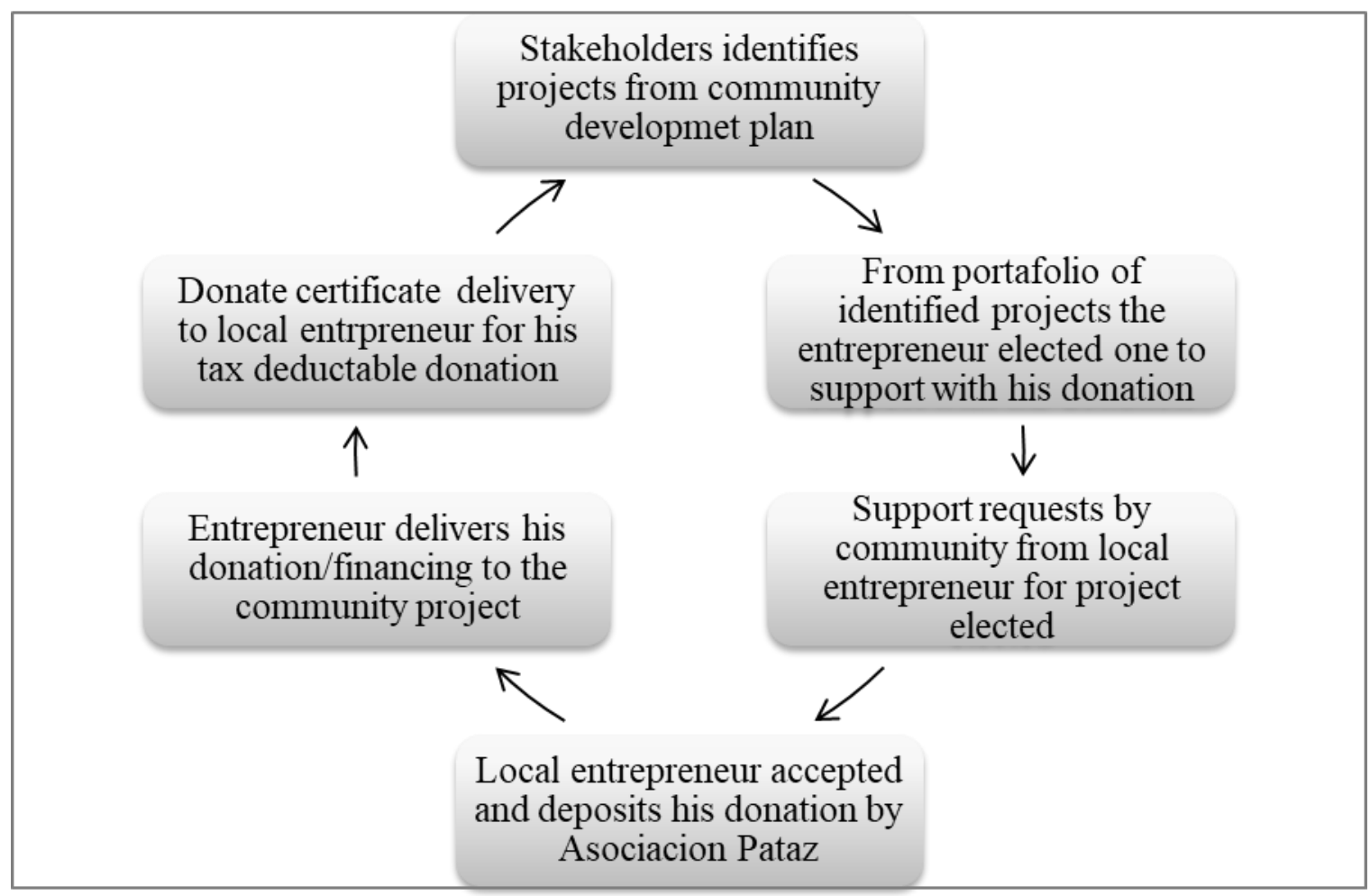

Figure 3. Protocol for the mobilization of donated funds.

These initiatives promote and incorporate the shared culture of social responsibility in entrepreneurs or local stakeholders, to create shared value with communities where they carry out their business activities. It is a process that previously involves the concerted planning, participation in joint work between local government, community, stakeholders and company, this multi-actor synergy has facilitated the cofinancing of community projects, the socialization of the portfolio of community projects through participatory events, awareness in financial models and donations, scope and benefits of shared practices of social responsibility, to make donations through the receiving entity following the abovementioned protocol, which is a process that concludes with the delivery of the certificate of donation by the receiving entity to the donor or local entrepreneur, who contributes to creating shared value with the surrounding communities. The results of this experience have enabled contributions from local stakeholders to [co]finance community projects of water, education and health together with the Mining Company in the district of Pataz, where the largest number of [co]finance cases have been for the water issues. 


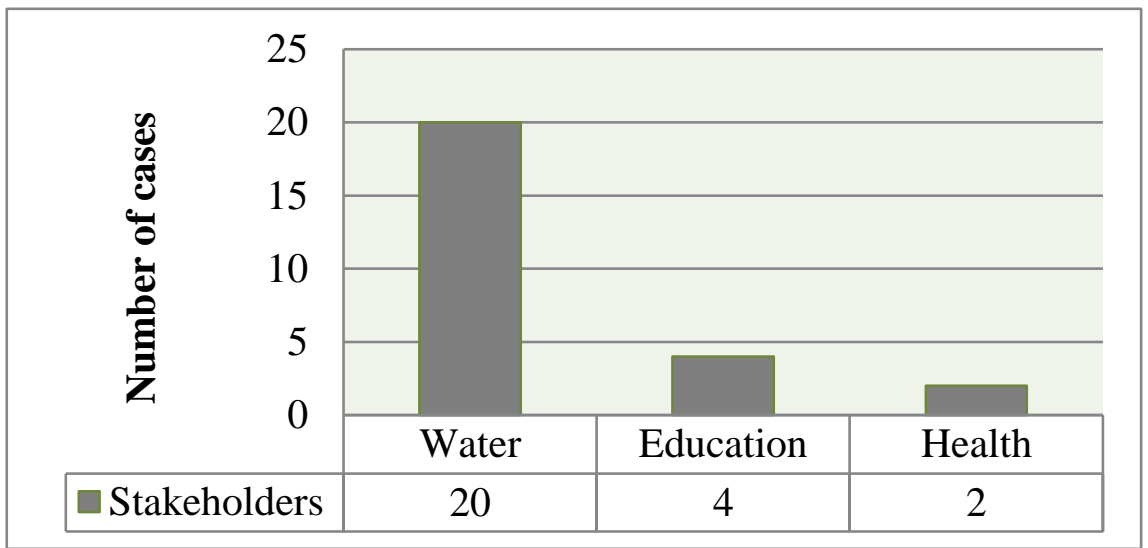

Figure 4. Cases of local entrepreneurs who have co-financed projects through donations

This experience of shared practices of social responsibility ${ }^{9}$, are a sui-generis experience that for the first time reveals the responsibility and engagement of the local enterprises to the communities where they undertake their business activities, recognizing themselves as part of the local environment. A fact that transcends local paradigms and effectively demonstrates the alliance between the mining company and local stakeholders to contribute to sustainable development, according to the social demands from the local community perspective and the risks of the business from the corporate perspective. This experience of shared values implies an innovation at the level product or service, at the level of value chain and at the level of business surrounding (Christensen, 2016), where issues of common interest are opportunities for multi-stakeholder collaboration to create shared values (Fraser, Kunz \& Batdorj, 2019) and a valuable strategy for corporate sustainability, therefore to address sustainable development (Murray, Haynes \& Hudson, 2010).

However, for the implementation of shared value creation experiences, it is necessary to manage good relations with the stakeholders (International finance corp., 2007) that will last throughout time (stability) and remain positive in space (surrounding). To build good stakeholders' engagement, it is not enough to have a well-developed sustainability report, or comply with [environmental] regulations. It is also necessary to regularly interact with the stakeholders, as these are

\footnotetext{
${ }^{9}$ These shared practices have enabled donation of approximately US\$200,000 of local stakeholders in an annual period, to co-finance community projects with an average budget of US\$30,000 each. This social investment, includes contributions from beneficiaries to community projects implemented, being the shared practices of social responsibility a potential to contribute to local development, whose progress is a process that goes through stages until adopting a business cultures that commitment to social an environmental issue. According to Zadek (2005) the process goes through five stages: defensive (deny), compliance (adopt), management (introduce), strategic (integrate) and civil (promote).
} 
more meaningful interactions, through proactive dialogue, active participation, direct communication, listening to what they say and sharing experiences are fundamental characteristic of good stakeholder engagement.
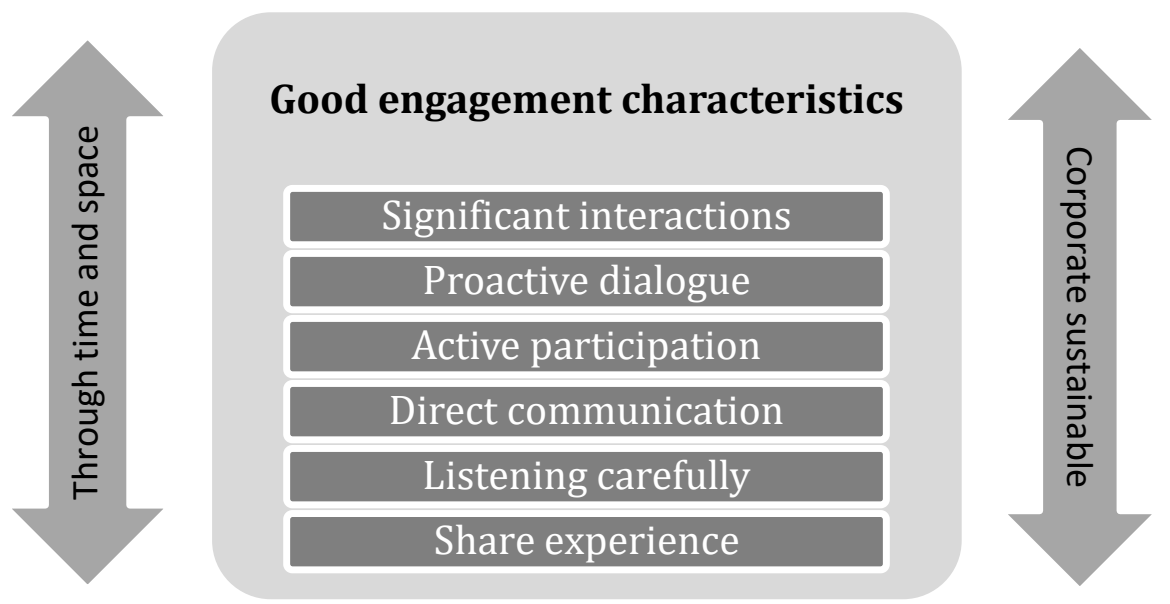

Figure 5. Good engagement characteristic of extractive industry with their stakeholder

Dorobantu, Henisz \& Nartey (2017) show that when a company has built a good relationship in time and space with stakeholders, they become friends (allies), stay with them and can even defend them from a crisis or a negative risk effect, while in companies with bad relationships, stakeholders tend to reiterate their opposition, generate negative opinions that contribute to the collapse of shareholder value and the collapse of potential market capitalization. In this regard Porter and Kramer (2016) argue that the most important thing a company do for society and for any community is to contribute to a prosperous economy. Several studies (Zairi \& Peters, 2002) (Dorobantu, Henisz \& Nartey, 2017) (Ioannou \& Serafeim, 2019) have demonstrated the relationship between sustainable practices and financial performance, the positive correlation between corporate social responsibility practices and profitability financial, the importance of building a good relationship with stakeholder to help corporate sustainability and avoid social risk, being this [co]relationship of bidirectional and simultaneous character (Nieto \& Fernandez, 2004)

"The relationship with mining company is good. Since we have been working together, we have agreed and continue to work together. The company shares with the people, before there was less of a relationship. I know that many things have happened and that there have been conflicts, but we have overcome them..." (Stakeholders: artisanal mining entrepreneur, 08/2016).

"As a strategic partner of company, I believe our relationship is better, we are moving forward, making CSR a shared responsibility was a great step forward and for us it is gratifying 
to see how the community receives us. Some of our collaborators are from the area, and MAROSE is already reaching the point of being a socially responsible company. We are already thinking of implementing works for taxes according to our capacity, we are already seeing our way forward..." (Stakeholders: local supplier entrepreneur, 11/2016).

These cases demonstrate the importance of building a good relationship with stakeholders through time (strategy) and space (practice), and this means investing in the relationship and gaining an understanding of the stakeholders. Unfortunately, very few companies do so with the necessary enthusiasm and seriousness, erroneously believing that building good relationships with the local community is symbolic or something good to have, with limited effects on the operations of the company or on the price of the shares, but the facts are showing that it is the opposite of what is happening, because a good relationship helps corporate sustainability. This, therefore, is proof that the value of the relationship is as important as the value of the shares (Dorobantu, Henisz \& Nartey, 2017).

Corporate social responsibility practices are not a nice gesture to do, but a critical issue of corporate performance (Zairi \& Peters, 2002). Thinking about social responsibility not as damage control, a public relations or marketing campaign, but as building of shared value, because the adoption of multi-stakeholder collaborative practices in the extractive industry through shared practices of corporate social responsibility helps to reduce social risk, enable collaborative actions, financial performance, corporate sustainability, continuing of operation, creating and shared value with local stakeholders (Fraser, Kunz y Batdorj, 2019), whose results ultimately contribute to sustainable development. Through strategic corporate social responsibility, the company causes the most significant social impact and reaps the best business benefits (Porter \& Kramer, 2006).

Carrying out shared practices of social responsibility with local stakeholders in a mining context of high social complexity, requires a meaningful and positive relationship, a good stakeholder engagement, fulfilling commitments, understanding the local perspective, knowing their willingness to share, and motivation to contribute (with shared cofinancing) to the implementation of sustainable development programs in the localities where they work. Achieving a genuine commitment between mining companies and local stakeholders, implies overcoming certain [local] barriers or paradigms to promote a culture of shared practices of corporate social responsibility with more local stakeholders. The corporate sustainability goes hand in hand with business success, social progress and environmental preservation, from that perspective, assuming a role as agent of sustainable development in the locations where they act as part of the concerted local planning process (Dejo. 
2005), enable the creation of shared value with local stakeholders in the district of Pataz.

\section{Conclusions}

In mining activity, economic, environmental and social performance is subject to internal scrutiny from corporate perception and the external scrutiny from local population perception, which responds to certain local and corporate paradigms, often reflecting in cultural barriers sources of social conflicts. Overcoming these paradigms (cultural barriers) from a vision of collaboration and participation, to enable social responsibility initiatives, corporate sustainability and to contribute to the sustainable development of their surroundings is ratified by the willingness of entrepreneurs or local stakeholders to carry out shared practices of social responsibility to co-finance community projects that generate shared values in the environments where they act and for their stakeholders.

Adopting a culture of social responsibility among local stakeholders or entrepreneurs is a sui-generis experience that reveals accountability and engagement with their social, environment and economic background, a fact that transcends local paradigms to make the alliance between the mining company, local entrepreneurs and other stakeholders a reality, based on an authentic relationship to create shared value, demonstrating the importance of the value of the relationship through time (permanence) and space (surrounding), not only for corporate sustainability but also to promote the sustainable development of the local population and surrounding communities, within the framework of a concerted local planning process.

\section{References}

Argandoña, A. (2011). La teoría de stakeholders y la creación de valor. IESE Documento de investigación, 922, 1-13.

Arbayza, L. Cateriano, J., \& Meza, I. (2014). Modelo de desarrollo sostenible en la pequeña minería subterránea: caso Kinacox. Lima, Peru: Esan.

Arrosquipa, P. (2014). Los elementos culturales de la organización empresarial. In Desco (Ed.), Perú hoy, mercado global y (des)articulaciones internas (pp. 138-176). Perú: Desco.

Arenas, D. Sánchez, P., \& Murphy, M. (2009). Relaciones empresariales con comunidades locales y ONG: comunicación, dialogo y participación. España: ESADE.

BID-CONFECAMARAS. (2018). Manual para la consultoría de responsabilidad social empresarial, (2da. Edición). Bogotá: 


\section{CONFECAMARAS.}

Bigné, E. Chumpitaz, R. Andreu, L., \& Swaen, V. (2005). Percepción de la responsabilidad social corporativa: un análisis cross-cultural. Universia business review, 5, 14-27.

Baba, M. (2012). Anthropology and business: influence and interests. Journal of business anthropology, 1(1), 20-71.

https://doi.org/10.22439/jba.v1i1.3546

Calveras, A., \& Ganuza, J. (2004). Responsabilidad social corporativa. Una visión desde la teoría económica. Cuadernos económicos de ICE, 76, 101118.

Christensen, K. (2016). La creación de valor compartido: entrevista a Michael Portes. Harvard deusto business review, 254, 76-82.

Correa, J. (2007). Evolución histórica de los conceptos de responsabilidad social empresarial y balance social. Semestre económico, 10(20), 87-102.

Cefkin, M. (2012). Close encounters: anthropology in the corporate arena. Journal of business anthropology, 1(1), 91-117.

https://doi.org/10.22439/jba.v1i1.3548

Dejo, F. (2005). Las empresas ante su desafío histórico: de la acumulación egoísta a la responsabilidad social. Cuadernos de difusión, 10(18-19), 91113.

De Pelekais, C., \& Aguirre, R. (2008). Unidad I: responsabilidad social empresarial. In Hacia una cultura de responsabilidad social. México D.F.: Pearson educación.

Damonte, G., \& Castillo, G. (2010). Presentación: una mirada antropológica a las industrias extractivas en los andes. Anthropologica, Año XXVIII, 28, 5-19.

Dorobantu, S. Henisz, W., \& Nartey, L. (2017). Not all sparks light a fire: stakeholders and shareholders reactions to critical events in contested markets. Administrative science quarterly, 62(3), 561-597. https://doi.org/10.1177/0001839216687743

Fraser, J. Kunz, N., \& Batdorj, B. (2019). Can mineral exploration projects create and share value with communities? A case study from Mongolia. Resources policy, 63, 1-9. https://doi.org/10.1016/i.resourpol.2019.101455

Friedman, M. (1970). The social responsibility of business is to increase its profits. The New York time magazine, 173-178. https://doi.org/10.1007/978-3-540-70818-6 14

Formentini, M., \& Taticchi, P. (2016). Corporate sustainability approach and governance mechanisms in sustainable supply chain management. Journal cleaner production, 112, 1920-1933. https://doi.org/10.1016/j.jclepro.2014.12.072 
Franco, P. (2007). Diagnostico de la responsabilidad social en el Perú. Documento de discusión DD/07/15. Lima: Universidad del Pacifico.

Fernández, R. (2005). Implicaciones estratégicas de la RSC y análisis de los stakeholders. In Administración de la responsabilidad social corporativa. Madrid: Thomson.

Gouley, C. (2005). Conflictos mineros, interculturalidad y políticas públicas: el caso de Las Bambas, provincia de Cotabambas y Grau, departamento de Apurímac. Informe final. Cusco: CBC, CIES.

Gomez, T. (2012). RSE y desarrollo sostenible. In E. Raufflet, J. Lozano, E. Barrera, \& C. Garcia. (Eds.), Responsabilidad social empresarial (pp. 5975). Mexico D.F.: Pearson.

Grupo propuesta ciudadana, (2019). Vigilancia de las industrias extractivas, Reporte nacional $N^{\circ} 23$, balance 2018. Lima: Vigila Perú.

Hütz-Adams, F., \&Müller, M. (2012). Brief 46 en la búsqueda del oro limpio: minería artesanal del oro en el Perú y en la RD del Congo, Boon: Boon International center for conversión.

International Finance Corporation, (2007). Stakeholder engagement: a good practice handbook for companies doing business in emerging markets. Washington D.C.: IFC World Bank.

INEI. (2017). Censos nacionales de población y vivienda 2017. Lima: Instituto nacional de estadística e informática.

Jenkins, H. (2006). Small business champions for corporate social responsibility. Journal of business ethics, 67, 241-256.

https://doi.org/10.1007/s10551-006-9182-6

Ioannou, I., \& Serafeim, G. (2019). Corporate sustainability: a strategy? Working paper, 19-065, Harvard business School. https://doi.org/10.2139/ssrn.3312191

Mitchell, R., Agle, B., \& Wood, D. (1997). Toward a theory of stakeholder identification and salience: defining the principle of who what really counts. Academy of management review, 22(4), 853-886. https://doi.org/10.2307/259247

Mendoza, A. (2019). Brechas latentes: índice de avance contra la desigualdad en el Perú 2017-2018. Lima: Oxfam.

Murray, A. Haynes, K., \& Hudson, L. (2010). Collaborating to achieve corporate social responsibility and sustainability? Possibilities and problems. Sustainability accounting, management and policy journal, 1(2), 161-177. https://doi.org/10.1108/20408021011089220

Nieto, A., M., \& Fernández, G., R. (2004). Responsabilidad social corporativa: la última innovación en management. Universia busines review-actualidad económica, primer trimestre, 28-39. 
Kemp, D., \& Owen, J. (2013). Community relations and mining: core to business but not core business. Resources policy, 38, 523-531.

https://doi.org/10.1016/j.resourpol.2013.08.003

Lopez, A., \& Contreras R. (2010). El concepto responsabilidad social empresarial desde diversos enfoques teóricos. Ideas concyteg, 5(58), 420 433.

Prahalad, C.K., \& Hammond, A. (2005). Atender a los pobres del mundo, rentablemente. Harvard business review, 83(8), 87-95.

Porter, M., \& Kramer, M. (2011). Creating shared value. Harvard business review, 89(1-2), 62-77.

Porter, M., \& Kramer, M. (2006). Estrategia y sociedad. Harvard business review america latina, 3-15.

Poderosa. (2015). Informe anual de sostenibilidad 2015, Perú: Compañía Minera Poderosa.

Pinto, H. (2015). Responsabilidad social empresarial de Xstrata Tintaya. Investigaciones sociales, 19(43), 169-182.

https://doi.org/10.15381/is.v19i34.11759

Peru2021. (2018). Distintivo empresa socialmente responsable. Lima:

Peru2021 Distintivo ESR.

Reficco, E., \& Ogliastri, E. (2009). Empresa y sociedad en América Latina: una introducción. Academia. Revista latinoamericana de administración, 43, 1-25.

Schwalb, M. (2008). ¿Qué es el desarrollo sostenible? In Responsabilidad social: fundamentos para la competitividad empresarial y el desarrollo sostenible. (Segunda edición). Lima: Centro de investigación de la Universidad del Pacifico.

UNDP. (2019). Human development report 2019.Lima: UNDP.

Zairi, M., \& Peters, J. (2002). The Impact of social responsibility on business performance. Managerial auditing journal, 17(4), 174-178. https://doi.org/10.1108/02686900210424312

Zadek, S. (2005). El camino hacia la responsabilidad corporativa. Harvard business review américa latina, 83(8), 54-63.

* An earlier version of this research was presented at the "4th international conference on social responsibility in mining' organized by GECAMIN, SMI CSRM, in Santiago Chile, November 2017, entitled "Shared Practices of Social Responsibility Through Stakeholders' Engagement" 


\section{Acknowledgements}

This research has enjoyed the unconditional support of the community relations area of the Poderosa Mining Company, and special thanks go out to Asociación Pataz and ACS Consultores for their support, thanks to local stakeholders (local supplier enterprises and artisanal mining enterprises formalized or in the process of formalization), who participated in the project, to Mr. Daniel Hewson, Director of Trends ELTS SRL for amendments to the English text.

Percy Arrosquipa has extensive job experience in sustainable development, social investment, and development management. After conducting his studies in anthropology at the National University of San Agustin, Arequipa Peru, he finished his MBA at ESAN Graduate School of Business at ESAN University, Lima Peru. He has participated as a lecturer in several international academic events, and has cofounded various entrepreneurial endeavors. His ethnographic research interests focus on sustainable development, economic anthropology, organizational culture and cross-cultural management. 